Original Research Paper

\title{
The Content of Heavy Metal in the Labu Riverbed Sediments: An Assessment of the Level of Pollution Applying Sediment Quality Guidelines and Geoaccumulation Index
}

\author{
Ahmad Shoaib Jahesh, Sahibin Abd Rahim and Wan Mohd Razli Idris \\ School of Environmental Sciences and Natural Resources, \\ Faculty of Science and Technology, University Kebangsaan Malaysia, 43600 Bangi Selangor Darul Ehsan Malaysia
}

\author{
Article history \\ Received: 23-03-2016 \\ Revised: 08-07-2016 \\ Accepted: 02-08-2016 \\ Corresponding Author: \\ Ahmad Shoaib Jahesh \\ School of Environmental \\ Sciences and Natural \\ Resources, Faculty of Science \\ and Technology, University \\ Kebangsaan Malaysia, 43600 \\ Bangi Selangor Darul Ehsan \\ Malaysia \\ Email: ahmad.jahesh@gmail.com
}

\section{Introduction}

Proliferation of heavy metal through anthropogenic activities is the greatest threat to river bed sediments quality. Heavy metal depositions and pollutions in river bed sediments could originate from several sources such as human activities (anthropogenic) or natural source. Anthropogenic sources may be linked to industry, agriculture, mining and construction of urban development which can transport polluted waters by rivers and its outlets (Sany et al., 2011). Lithogenethic sources could be associated with natural cause such as

\begin{abstract}
River bed sediments from thirteen (13) sampling stations, from Labu River were collected in June and December 2014. The aim is to identify the source and ascertain the current levels of heavy metal pollutions. The selected heavy metals ( $\mathrm{Cr}, \mathrm{Cu}, \mathrm{Fe}, \mathrm{Ni}, \mathrm{Zn}, \mathrm{As}, \mathrm{Cd}$ and $\mathrm{Pb}$ ) were analysed by using Inductively Couple Plasma Mass Spectrophotometry (ICPMS). Metals were statistically analysed and compared with Dutch/Malaysia Sediments Quality Guidelines (Target and and PEL). Geoaccumulation index (Igeo) was calculated and metals were classified. The results showed that the mean value for $\mathrm{Cr}$ is $19.74 \pm 10.36$ $\mathrm{mg} \mathrm{kg}{ }^{-1}, \mathrm{Cu}\left(7.33 \pm 2.35 \mathrm{mg} \mathrm{kg}{ }^{-1}\right) ; \mathrm{Fe}\left(7636.39 \pm 26.38 \mathrm{mg} \mathrm{kg}^{-1}\right)$; As $\left(11.67 \pm 3.59 \mathrm{mg} \mathrm{kg}{ }^{-1}\right)$; $\mathrm{Cd}\left(0.097 \pm 0.03 \mathrm{mg} \mathrm{kg}^{-1}\right)$ and $\mathrm{Pb}(26.23 \pm 5.33 \mathrm{mg}$ $\left.\mathrm{kg}^{-1}\right)$. The compared sediment guidelines revealed that $\mathrm{Cr}\left(51.55 \mathrm{mg} \mathrm{kg}^{-1}\right)$ in SW9, Pb in SW1 (36.43 mg kg-1) and SW13 (37.42 mg kg-1) and As in all of the stations (SW1-SW13) did not meet the Canadian ISQG and were polluted. The geoaccumulation index (Igeo) showed that, $\mathrm{Cr}(-3.38 \pm 0.17)$, $\mathrm{Cu}(-3.22 \pm 0.12), \mathrm{Ni}(-3.37 \pm 0.24), \mathrm{Zn}(-2.14 \pm 0.23), \mathrm{Cd}(-3.38 \pm 0.17)$ and $\mathrm{Pb}$ $(-3.22 \pm 0.12)$ were practically uncontaminated. However, As $(2.14 \pm 0.13)$ was classified as moderately contaminated. Based on mean concentrations of heavy metals with the compared Sediments Quality Guidelines (SQG) and Index, it is concluded that As is the heavy metal of concern in the Labu catchment. There is need for the authorities to pay more attentions to sediment pollution problem due to As and address riverbed sediment pollution problems in the different locations as indicated by ISQG due to anthropogenic influences from the KLIA, Dengkil sand mine and Agriculture developments projects in the study area.
\end{abstract}

Keywords: Heavy Metal, Sediment Quality Guidelines, Geoaccumulation Index, Labu Rive, Malaysia weathering of rocks that tend to enrich river bed with heavy metal laden sediments (Farkas et al., 2007). The main concern is the amount of heavy metals entering into river bed sediments via infiltrations from river water. In the worst cases the heavy metal content might be several orders of magnitude higher than in the water phase itself (Wojtkowska, 2011). This metal from receiving surface water migrates and is remobilized to the underlying bottom sediments. Therefore, the bottom sediments act as the ultimate sink for these metals. The fact is that bottom sediments have high absorption capacity with regard to trace elements and acts as the 
receptor or main factor of river water self-purification that drain heavy metal compounds from the impacted surface water (Tanghinia et al., 2010). According to this same author the distribution and accumulation of metals are most often, strongly influenced by mineralogical composition, sediment texture, adsorption, desorption processes and oxidation-reduction state and physical transport. According to Wei and Yang (2010) the pollution sources of heavy metals in environment are mainly derived from anthropogenic sources while Wojtkowska (2011) is of the opinion that the development of civilization through human activities has contributed immensely to the introduction of heavy metals into the natural environment in amounts remarkably exceeding the natural load and the bottom sediments accumulate many elements, some of which are heavy metals and could be hazardous for natural environment, as well as animals and people.

Heavy metals have some ecological significance. However, they are equally dangerous, highly reactive, bio accumulative and extremely toxic elements when found above guidelines concentrations. Unlike organic contaminants which are oxidized by microbial action, most metals do not undergo microbial or chemical degradation (Kirpichtchikova et al., 2006). Heavy metals are not biodegradable and are persistent in the environment (MacFarlane et al., 2007).

In Malaysia, Labu catchment represents a typical Langat Basin Tributary under stress from continuing urban development, agricultural development and mining activities. Previous studies show that water quality is affected. According to Hoo et al. (2005). The main Labu River received pollutants from construction projects around Kuala Lumpur International Airport (KLIA). Expansions of irrigated agriculture, rapid urbanization, industrialization and deforestation have had significant negative impact on the Labu catchment water quality and its associated ecosystem which are aligned within transect of the Langat Basin. The evaluation of metal distribution in the riverbed sediments could therefore be a useful tool to assess the pollution in the aquatic environment (Salomons and Forstner, 1984) and the total content of heavy metals in the bottom sediments could be used to estimate the level of pollution (Wojtkowska, 2011). The aim of this current study is to identify the source and ascertain the current levels of heavy metal pollutions in the Labu catchment.

\section{Materials and Methods}

\section{Study Area}

The study area is the Labu catchment which lies between longitude $101^{\circ} 40^{\prime} 07^{\prime \prime} \mathrm{E}$ to $101^{\circ} 50^{\prime} .71^{\prime \prime} \mathrm{E}$ and latitude $02^{\circ} 49^{\prime} 14.43^{\prime \prime} \mathrm{N}$ to $02^{\circ} 44^{\prime} .76{ }^{\prime \prime} \mathrm{N}$ in Western Malaysia (Fig. 1). The Labu catchment is between Seremban and Nilai and extends to Dengkil town. The total area extent of the catchment is about $263.60 \mathrm{~km}^{2}$ (APN and EOC, 2013). This comprise of three main tributaries: Batang Labu (about 17.9 kilometers), the Batang Nilai (6.4 kilometers) and the main Sungai Labu which is about $31.1 \mathrm{~km}$ (Table 1). Sungai Labu alone has a catchment area of about 185 square kilometers and is one of the main tributaries of the Sungai Langat. They build up extensive coastal plain with river Semenyih in the western part of the area (APN and EOC, 2013). The Labu River flows are from the Territorial divisions of Labu, Seremban and flow through the town of Nilai and finally meet Langat River at about $3 \mathrm{~km}$ south of Dengkil town (Fig. 1). The Labu River and the Langat Rivers are part of the extensive flows that make up the Langat Basin in Malaysia.

The location of the Labu catchment allows it to enjoy equatorial climate with annual average temperatures between 20.5 and $36^{\circ} \mathrm{C}$. Shaharuddin and Noorazuan (2006) stated that the area has two distinctive rainfall patterns that is moderately dry and moist and receives the lowest yearly rainfall for Peninsular Malaysia. The mean monthly relative humidity range is $80.6-85.6 \%$ (Sheriza et al., 2011). The soil of the study area is covered mainly by (i) weathered Kenny Hill formation and (ii) quarternary alluvium (which are made up of unconsolidated to semi-consolidated peat, clay, silt, sand and gravel (Adnan et al., 2013). The area includes different main land uses such as agricultural land, settlements, industry, forests, industry, development projects, water bodies and post landfill practices. A palm oil plantation exists at Dengkil at Sepang district (Adnan et al., 2013). River banks are wide and flat with many villages and infrastructure including highways. Moreover, Labu is known as the main home of Malay art work specifically pottery and potters often use earthenware clay from river bed sediments (Mohammed, 2005). Labu River also provides water resource mainly to the Salak Tinggi treatment plant, to cater for Salak Tinggi and Sepang areas (Hoo et al., 2005). Figure 1 shows the Map of Labu catchment in relation to Malaysia while Table 1 shows the GPS position of the selected riverbed sampling locations and description of the study area in Labu River Catchment.

\section{Riverbed Sediment Sampling}

The sampling was carried out in June (dry season) and December (rainy season) 2014. River bed sediments from 13 rivers were collected by using grab-sampler. The locations of the sampling points were identified through the use of hand-held Global Positioning System (GPS) and were designated using format code SW1 to SW13 (Table 1). Samples were collected in such a way that they collectively represent upstream and downstream of the study area to make comparison between the sampling points and to understand intensively the area of most activity and pollutions in the study site. 


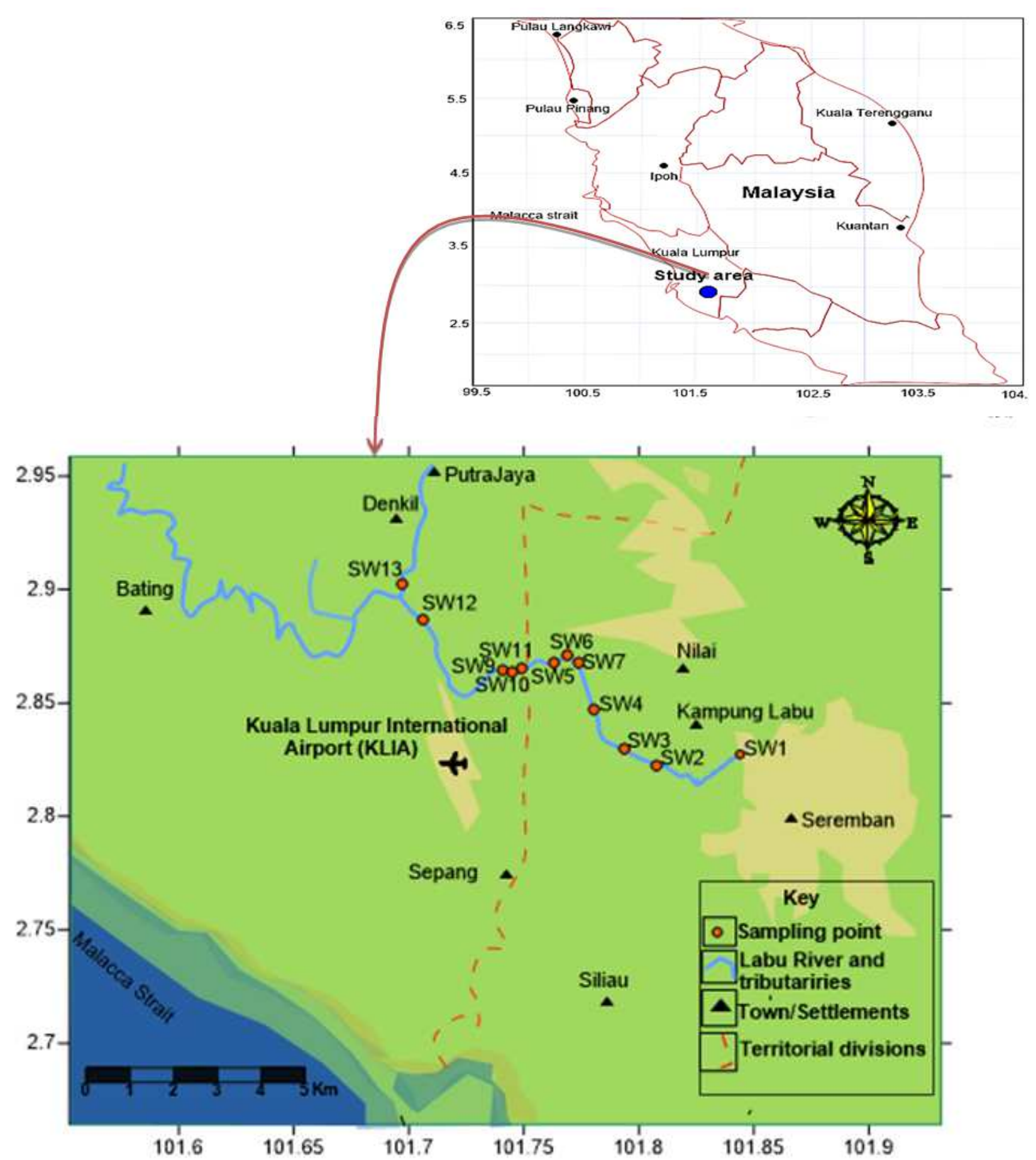

Fig. 1. Map of Labu catchment in relation to Malaysia, Note: Co-ordinates are specified in decimal degrees and are consistent with GPS coordinates in Table 1, Source: Adapted and Modified from Google earth image 2016

Four (4) samples were collected at the upstream (SW1SW4); five (5) were concentrated at the midstream stations (SW5-SW7, SW11 and SW8) while four (4) samples were collected at the downstream area at both the immediate downstream (SW9 and SW10) and furthest downstream (SW12 and SW13) stations. Approximate $1 \mathrm{~kg}$ of river bed sediments samples were collected at sampling points. Samples were labeled and store in cool box at the $4^{\circ} \mathrm{C}$ prior to further analysis at the laboratory of University Kebangsaan Malaysia (UKM). 
Table 1. GPS Co-ordinates of the selected riverbed sampling locations and description of the study area in Labu River Catchment GPS Co-ordinates

\begin{tabular}{|c|c|c|c|c|}
\hline Sampling stations & Location & Latitude & Longitude & Description \\
\hline SW1 & Batang Labu & $\mathrm{N} 02^{\circ} 45.26$ & $101^{\circ} 52.17 \mathrm{E}$ & Kampung Pasir Putih \\
\hline SW2 & Batang Labu & $\mathrm{N} 02^{\circ} 44.76$ & $101^{\circ} 50.71 \mathrm{E}$ & Kampung Tekir village \\
\hline SW3 & Batang Labu & $\mathrm{N} 02^{\circ} 45.20$ & $101^{\circ} 49.34 \mathrm{E}$ & Labu Town \\
\hline SW4 & Batang Labu & $\mathrm{N} 02^{\circ} 45.68$ & $101^{\circ} 48.39 \mathrm{E}$ & Kampung Pulau \\
\hline SW5 & Batang Labu & $\mathrm{N} 02^{\circ} 47.83$ & $101^{\circ} 46.90 \mathrm{E}$ & Kampung Tanjung \\
\hline SW6 & Batang Nilai & $\mathrm{N} 02^{\circ} 47.84$ & $101^{\circ} 46.90 \mathrm{E}$ & Kampung Tanjung \\
\hline SW7 & Labu river & $\mathrm{N} 02^{\circ} 47.83$ & $101^{\circ} 46.91 \mathrm{E}$ & Kampung Tanjung \\
\hline SW8 & Chinchang River & $\mathrm{N} 02^{\circ} 78.66$ & $101^{\circ} 74.51 \mathrm{E}$ & Kampung Tanjung \\
\hline SW9 & Labu river & $\mathrm{N} 02^{\circ} 78.93$ & $101^{\circ} 73.75 \mathrm{E}$ & Kampung Tanjung \\
\hline SW10 & Ayar Hitam River & $\mathrm{N} 02^{\circ} 77.63$ & $101^{\circ} 71.26 \mathrm{E}$ & Kampung Ayer Hitam \\
\hline SW11 & Labu river & $\mathrm{N} 02^{\circ} 47.23$ & $101^{\circ} 45.02 \mathrm{E}$ & Salak Tinggi \\
\hline SW12 & Labu river & $\mathrm{N} 02^{\circ} 48.33$ & $101^{\circ} 41.46 \mathrm{E}$ & Salak Tinggi \\
\hline SW13 & Labu river & $\mathrm{N} 02^{\circ} 49.43$ & $101^{\circ} 40.07 \mathrm{E}$ & Dengkil sand mine \\
\hline
\end{tabular}

\section{Samples Preparation and Pretreatment}

Chemical Analysis was carried out in the Soil Laboratory of University Kebangsaan Malaysia (UKM). Eight (8) heavy metal parameters analyzed in sediment samples included: $\mathrm{Cr}, \mathrm{Cu}, \mathrm{Fe}, \mathrm{Ni}, \mathrm{Zn}, \mathrm{As}, \mathrm{Cd}$ and $\mathrm{Pb}$. The samples were air dried at the laboratory at room temperature for 3 days $(72 \mathrm{~h})$. Further oven drying was carried out overnight $(24 \mathrm{~h})$. The oven dried soil samples were thoroughly broken up and was further prepared and cleaned by removing stones, plant residues and grounded to pass through $63 \mu \mathrm{m}$ sieves.

\section{Digestion of Samples for Heavy Metal Analysis by} ICPMS

About $1.00 \mathrm{~g}$ of soil samples was digested by nitric/per chloric acid digestion based on the EPA SW 846 method 3050 prescribed by Kimbrough (1989). About $15 \mathrm{~mL}$ of concentrated $\mathrm{HNO}_{3}$ and $5 \mathrm{~mL} \mathrm{HClO}_{4}$ were added to the sediment samples and reflux for $3 \mathrm{~h}$ at a temperature of $95^{\circ} \mathrm{C}$. The samples were then filtered with $0.45 \mu \mathrm{m}$ whatman filter paper attached to a suction pump. Duplicates for each sample were prepared and were reconstructed to $50 \mathrm{~mL}$ mark with deionized water. Diluted samples were placed in a centrifuge tube and were shaken to mix and ready for ICPMS analysis. A method blank was also prepared following the same procedures used for the sample with the exceptions that no sediments samples were added. The blank were later subtracted from the reading obtained from ICPMS which were in part per billion concentrations. This was further recalculated back to $\mathrm{mg} / \mathrm{kg}$ concentrations levels of the heavy metals in the soil samples. The average was recorded as the concentration of the trace metal in $\mathrm{mg} / \mathrm{kg}$ concentrations. The expression in Equation 3 below was used to calculate the concentrations back to the true concentration in $\mathrm{mg} / \mathrm{kg}$.
Calculations of Heavy Metal Concentration in Sediments to $\mathrm{mg} / \mathrm{kg}$ Level

About $1 \mathrm{~g}$ of sediments was dissolved by various reactions into $50 \mathrm{ml}$. The ratio therefore is 1:50 and results are multiplied by 50 . However the steps in reaching the calculations are expressed in Equation 1-3 according to Sakawi et al. (2013):

Using $\mathrm{Cr}$ as an example:

$$
H_{a}-H_{b}=H c(\text { e.g., Cr as calculated })
$$

Therefore:

About $1.00 \mathrm{~g}$ of soil sample dissolved by various reactions in 1 liter contains:

$$
(50 / 1000) / 1\left(H_{c}\right)
$$

Hence, $\mathrm{mg} / \mathrm{g}$ level of soil sample contains:

$=0.05\left(H_{c}\right)$

About $1 \mathrm{~kg}$ of the soil samples therefore contains:

$=\left(0.05 H_{c}\right) 1000$

Where:

$1.00=$ Mass of soil sample used $(\mathrm{g})$

$50=$ Final volume of solutions $(\mathrm{mL})$

$H_{a}=$ Concentrations of heavy metal as read from ICPMS

$H_{b}=$ Blank concentration value from ICPMS

$H_{c}=$ Concentration of heavy metals (e.g., Cr) mg/L as calculated from Equation 1

The calculations were applied for each of the eight heavy metal concentrations and averages were taken and reported as the concentration of heavy metal in river bed sediments $\mathrm{mg} / \mathrm{kg}$ level for Labu Catchment. 


\section{Statistical Data Analysis}

The descriptive statistics of mean, Standard Deviation (SD) minimum and maximum values was used to describe and show the index of the amount of variability in the data sets. Analyses were carried out with Statistical Package for Social Science (SPSS, 2013) software. Inference statistics such as correlation analysis and was further used to measure the intensity of association observed between the data in order to verify relationship between the sample points and to show the significant levels. Positive relationships suggested increased concentrations of the associated metals towards each other and negative showed a decrease in concentrations between the associated metals.

\section{Comparing with Sediment Quality Guidelines (SQG)}

Sediment Quality Guidelines (SQG) is reliable indicators of pollution levels. Therefore, since the Malaysian soil standard is adopted from Dutch Soil Protection Act (Swartjes, 1999; Ismail et al., 2015) the results from the statistical analysis obtained in this study were further compared with (i) the Dutch sediment guidelines intervention and Target values/Malaysia soil standard (Swartjes, 1999). An additional guidelines values was adopted which is (ii) the Canadian Sediment Quality Guidelines for the Protection of Aquatic Life for freshwater sediment for Interim Sediment Quality Guideline (ISQG) and Probable Effect Level (PEL) (CCME, 2002). By interpretations, the Dutch intervention values indicate potential risk to human and ecosystem while the Target values indicate the potential risk to ecosystem (Swartjes, 1999). On the other hand, Interim Sediment Quality Guideline (ISQG) is national and temporary sediment quality levels to detect adverse biological effects while the Probable Effect Level (PEL) represents the lowest limit range of chemical concentrations that are usually or always associated with adverse biological effects (Gharibreza et al., 2013). These two (the Malaysian/Dutch and Canadian) standard guidelines were compared to ascertain the pollution level in the study area.

\section{Geoaccumulation Index}

The level of anthropogenic contamination was further assessed by calculating the Geoaccumulation index (Igeo). Geoaccumulation Index (Igeo) has been expressed by Muller (1981) according to the Equation 4:

$$
\text { Igeo }=\log _{2}\left[C n / 1.5 B_{n}\right]
$$

Where:

$C_{n}=$ the concentration (mean) of heavy metals as calculated $(\mathrm{mg} / \mathrm{kg})$

$B_{n}=$ the geochemical background value of shale $(\mathrm{mg} / \mathrm{kg})$ $1.5=$ the correction factor due to lithological variations
Table 2. Geoaccumulation index classifications

\begin{tabular}{lll}
\hline $\begin{array}{l}\text { Sediment Igeo } \\
\text { contamination } \\
\text { value }\end{array}$ & $\begin{array}{l}\text { Geoaccumulation } \\
\text { class Intensity }\end{array}$ & $\begin{array}{l}\text { Index, Igeo } \\
\text { (sediment quality) }\end{array}$ \\
\hline$>5$ & 6 & Very strong \\
$>4-5$ & 5 & Strong to very strong \\
$>3-4$ & 4 & Strong \\
$>2-3$ & 3 & Moderate to strong \\
$>1-2$ & 2 & Moderate \\
$>0-1$ & 1 & Uncontaminated to \\
& & moderate \\
$>0$ & 0 &
\end{tabular}

Source: Gupta et al. (2014)

The geoaccumulation index (Igeo) approach compares the measured concentration of the element in the sediments fraction $\left(C_{n}\right)$ with the geochemical background value $\left(B_{n}\right)$ and thereby quantifies the degree of anthropogenic contamination. The geochemical background value of global average shale according to Wedepohl (1995) are most often use as reference point and was taken as the reference value $\left(B_{n}\right)$ presented in Table 3. The factor 1.5 is the multiplication or matrix correction factor that takes into account possible lithological fluctuations in the background trace elements. This correction factor aid to detect the slightest anthropogenic inputs. Furthermore, geoaccumulation index classification are represented as seven grades according to Forstner et al. (1993) and were used to show the contamination levels as tabulated in Table 2 .

The Igeo value in the class intensity of zero (0) indicates the absence of contamination and the Igeo value in class 6 intensity represents the upper limits of maximum contamination (Boszke et al., 2004) or 100-fold enrichment above background values (Praveena et al., 2008).

\section{Results and Discussion}

Results on Pollution Levels by Comparing with Sediment Quality Guidelines (SQG) and Applying Correlation Coefficient Factor

The results in Table 3 are the descriptive statistics of investigated heavy metal parameters for river bed sediments and the comparison with the Dutch sediment guidelines and Canadian sediment quality guidelines values.

\section{Chromium (Cr)}

The results showed that the mean $\mathrm{Cr}$ concentration $\left(19.74 \pm 10.36 \mathrm{mg} \mathrm{kg}{ }^{-1}\right)$ recorded in all of the stations were not similar and widely varied. Generally, the lowest $\mathrm{Cr}$ concentrations were observed at the upstream stations (SW1-SW4) while the highest concentration was at SW9 (51.55 mg kg-1) and followed by a relatively higher concentration at $\mathrm{SW} 10$ (26.56 mg kg $\square 1$ ). Both of this midstream stations (SW9 and SW10) are located in the Labu River tributaries at Kampung Tanjung area and are among the locations closest to the KLIA. 
Table 3. Mean and standard deviation value of selected heavy metal parameters for river bed sediments (in $\mathrm{mg} / \mathrm{kg}$ )

\begin{tabular}{|c|c|c|c|c|c|c|c|c|}
\hline Parameters & $\mathrm{Cr}$ & $\mathrm{Cu}$ & $\mathrm{Fe}$ & $\mathrm{Ni}$ & $\mathrm{Zn}$ & As & $\mathrm{Cd}$ & $\mathrm{Pb}$ \\
\hline$\overline{\text { SW1 }}$ & 15.29 & 8.00 & 5695.8 & 6.24 & 19.77 & 11.57 & 0.05 & 36.43 \\
\hline SW2 & 14.29 & 6.14 & 5010.4 & 5.74 & 21.07 & 9.61 & 0.08 & 24.81 \\
\hline SW3 & 13.92 & 5.60 & 6289.0 & 4.80 & 21.91 & 8.07 & 0.10 & 27.88 \\
\hline SW4 & 11.70 & 4.77 & 4721.1 & 4.36 & 18.33 & 6.59 & 0.07 & 25.39 \\
\hline SW5 & 21.81 & 10.21 & 10707.7 & 8.21 & 55.32 & 19.97 & 0.13 & 26.36 \\
\hline SW6 & 19.94 & 12.49 & 10085.1 & 12.82 & 43.45 & 17.59 & 0.11 & 22.32 \\
\hline SW7 & 13.51 & 8.10 & 6785.1 & 12.12 & 23.11 & 12.77 & 0.10 & 26.23 \\
\hline SW8 & 15.35 & 5.54 & 5865.8 & 6.72 & 21.94 & 10.92 & 0.11 & 18.68 \\
\hline SW9 & 51.55 & 9.15 & 8737.2 & 32.25 & 49.83 & 11.85 & 0.15 & 23.34 \\
\hline SW10 & 26.56 & 8.39 & 7819.4 & 13.69 & 32.23 & 11.23 & 0.12 & 22.69 \\
\hline SW11 & 17.85 & 7.02 & 9163.3 & 5.65 & 35.91 & 9.47 & 0.09 & 26.89 \\
\hline SW12 & 15.92 & 5.18 & 9022.5 & 5.32 & 114.28 & 10.77 & 0.09 & 22.66 \\
\hline SW13 & 18.99 & 4.68 & 9370.4 & 5.26 & 55.48 & 11.32 & 0.06 & 37.42 \\
\hline Mean & 19.74 & 7.33 & 7636.39 & 9.48 & 39.43 & 11.67 & 0.097 & 26.23 \\
\hline$\pm \mathrm{SD}$ & \pm 10.36 & \pm 2.35 & \pm 2015.98 & \pm 7.56 & \pm 26.38 & \pm 3.59 & \pm 0.03 & \pm 5.33 \\
\hline $\begin{array}{l}{ }^{\text {aD }} \text { Dutch/Malaysian target } \\
\text { values and soil standard }\end{array}$ & 100 & 36 & NA & 35 & 140 & 29 & 0.8 & 85 \\
\hline $\begin{array}{l}\text { aDutch intervention values/ } \\
\text { Malaysian soil standard }\end{array}$ & 380 & 190 & NA & 210 & 720 & 55 & 12 & 530 \\
\hline aCCME (ISQG) & 37.30 & 35.7 & NA & NA & 123 & 5.90 & 0.60 & 35.0 \\
\hline${ }^{\mathrm{a} C C M E}$ (PEL) & 90.00 & 197 & NA & NA & 315 & 17.0 & 3.50 & 91.0 \\
\hline$* \mathrm{Bn}$ & 126 & 45 & NA & 56 & 95 & 1.7 & 0.1 & 14.8 \\
\hline
\end{tabular}

Note: \pm denotes Standard Deviation (SD); bold figure indicate heavy metal concentrations of concern in the different stations; NA- not available; ${ }^{a}$ Dutch Sediment Guideline Target and Intervention values/Malaysia soil standard (for soil containing $10 \%$

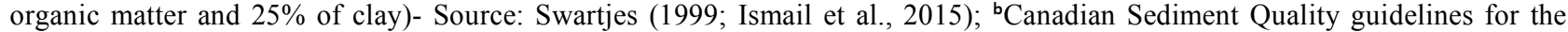
Protection of Aquatic Life, ISQG and PEL- source: CCME (2002). *Bn- indicates geochemical background value of global average shale- Source: Wedepohl (1995)

However, relatively, higher concentrations of $21.81 \mathrm{mg}$ $\mathrm{kg}^{-1}$ than the upstream and midstream areas were recorded in SW5 at Batang Labu waters. The differences in the highest $\mathrm{Cr}$ concentrations at upstream station SW9 and lowest upstream station SW4 $\left(1.70 \mathrm{mg} \mathrm{kg}^{-1}\right)$ is large at $39.85 \mathrm{mg} \mathrm{kg}^{-1}$ concentrations and indicating that some activity were promoting the elevated levels of Cr in SW5 and were more prevalent at SW9 stations. Furthermore, when the mean $\mathrm{Cr}$ concentration $\left(19.74 \mathrm{mg} \mathrm{kg}^{-1}\right.$ ) was compared with the Dutch/Malaysian soil standard and Canadian ISQG and PEL values the results showed that the $\mathrm{Cr}$ concentrations in all of the thirteen (13) stations were well below the Dutch/Malaysian standard value (both Intervention and Target value). However, the exception is that with reference to the Canadian ISQG that was set at $37.30 \mathrm{mg} \mathrm{kg}^{-1}$, the $\mathrm{Cr}$ concentrations in SW9 have exceeded these limits and therefore is said to be polluted. Contrary, $\mathrm{Cr}$ concentration in the different stations and the mean value are below the average shale $\left(B_{n}\right)$ value of $126 . \mathrm{Cr}$ is a major constituent of $\mathrm{Cr}$ pigment, electroplating sludge. These are major byproducts associated with construction activities. Barałkiewicz and Siepak (1999) also pointed out that the higher content of $\mathrm{Cr}$ in the environment is majorly caused by human activity. According to Smith et al. (1995) most of $\mathrm{Cr}$ released into natural waters is particle associated and ultimately deposited into sediment. This imply that $\mathrm{Cr}$ may have been washed to bottom sediments as dust and particles from construction and expansion projects around KLIA, which is closer to SW9 and SW10. The implication of $\mathrm{Cr}$ is that high doses can cause liver and kidney damages while chromate dusts are known to be carcinogenic (Lin et al., 2002; Aboud and Nandini, 2009). Chromium is also linked with allergic dermatitis in humans (Scragg, 2006). Thus, as indicated by ISQG, $\mathrm{Cr}$ is a major concern in the SW9 station.

\section{Copper (Cu)}

The highest concentrations of $\mathrm{Cu}$ were at SW5 (10.21 $\mathrm{mg} \mathrm{kg}$ ) and SW6 (12.49 mg kg-1) in the tributaries of Batang Labu and Batang Nilai respectively (Table 1). SW5 is the same stations where some relatively higher $\mathrm{Cr}$ concentrations were recorded (Table 3 ). However, the general trend exhibited by $\mathrm{Cu}$ concentrations in all of the river bed sediments from the thirteen investigated stations were in irregularly high and low concentrations pattern from upstream to downstream stations. This suggests that the concentration ion of this metal $(\mathrm{Cu})$ in the river bed were mainly dependent on the sampling locations. The mean value of $\mathrm{Cu}\left(7.33 \pm 2.35 \mathrm{mg} \mathrm{kg}^{-1}\right)$ shows that the concentrations were low when compared to the concentrations of other metals. The deviation value tells that the concentrations in all of the investigated stations were not widely varied. The lowest $\mathrm{Cu}$ concentration recorded is at the Dengkil Sand mine in SW3 $\left(4.68(\mathrm{mg} \mathrm{kg})^{-1}\right)$. Relatively higher $\mathrm{Cu}$ concentrations recorded at SW6 and SW5 are related to activities specific to the locations. Results of correlation coefficient analysis of mean $\mathrm{Cu}$ concentrations of some heavy metals are presented in Table 4. 
Table 4. Correlation Coefficient (r) factor of heavy metals investigated in the River bed sediment in Labu Catchment

\begin{tabular}{llllllll}
\hline & $\mathrm{Cr}$ & $\mathrm{Cu}$ & $\mathrm{Fe}$ & $\mathrm{Ni}$ & $\mathrm{Zn}$ & $\mathrm{As}$ & $\mathrm{Cd}$ \\
\hline $\mathrm{Cr}$ & 1 & & & & & & \\
$\mathrm{Cu}$ & 0.411 & 1 & & & & & \\
$\mathrm{Fe}$ & 0.403 & 0.524 & 1 & & & & \\
$\mathrm{Ni}$ & $0.933^{* * *}$ & 0.522 & 0.279 & 1 & & & \\
$\mathrm{Zn}$ & 0.202 & -0.017 & $0.645^{*}$ & 0.0678 & 1 & & \\
$\mathrm{As}$ & 0.222 & $0.806^{* * *}$ & $0.697^{* *}$ & 0.2489 & 0.2649 & 1 & 1 \\
$\mathrm{Cd}$ & $0.667^{* *}$ & $0.577^{*}$ & 0.455 & $0.7060^{* *}$ & 0.18244 & 0.4915 & $-0.677^{* *}$ \\
$\mathrm{~Pb}$ & -0.181 & -0.198 & 0 & -0.288 & -0.096 & -0.076 & 1 \\
\hline
\end{tabular}

Note: Number of samples $(\mathrm{n})=13 ; \mathrm{r}=0.532^{*} ; \mathrm{r}=0.661^{* *} ; \mathrm{r}=0.780^{* * *}$

The results show that $\mathrm{Cu}$ is strongly correlated $0.1 \%$ level with As $\left(\mathrm{r}=0.806^{* * *}\right), \mathrm{Cd}\left(\mathrm{r}=0.577^{*}\right)$ and $\mathrm{Fe}(\mathrm{r}=$ 0.524). This suggests that some similar activity in the stations were promoting $\mathrm{Cu}, \mathrm{As}, \mathrm{Cd}$ and $\mathrm{Fe}$ concentrations. The coefficient factor $(\mathrm{r})$ between $\mathrm{Cu}$ and $\mathrm{Cr}(\mathrm{r}=0.411)$ were positive and of weak effect, buttressed the fact further that $\mathrm{Cr}$ and $\mathrm{Cu}$ were due to different activity or sources in the study area. $\mathrm{Cr}$ was observed to be polluting the sediments at SW9 and was related to the KLIA development activities. However, $\mathrm{Cu}$ were due to other activities or conditions in the study area and may not be associated with the KLIA.

\section{Cadmium (Cd)}

The concentrations of $\mathrm{Cd}$ in the locations are below the limit of the compared standards and the average shale $(\mathrm{Bn})$ value (45). The mean value of $\mathrm{Cd}$ is $0.097 \pm 0.03 \mathrm{mg}$ $\mathrm{kg}^{-1}$. Therefore, $\mathrm{Cd}$ is not a major heavy metal of concern in the river bed sediment at Labu catchment. Relative high concentrations of $\mathrm{Cd}$ were recorded at SW9 (0.15 $\left.\mathrm{mg} \mathrm{kg}^{-1}\right)$ and SW5 $\left(0.13 \mathrm{mg} \mathrm{kg}^{-1}\right)$. These two locations (SW9 and SW5) are similar stations where relatively high concentration of $\mathrm{Ni}\left(32.25 \mathrm{mg} \mathrm{kg}^{-1}\right)$ and $\mathrm{Cu}\left(10.21 \mathrm{mg} \mathrm{kg}^{-1}\right)$ were recorded respectively. Correlation analysis showed that relation between $\mathrm{Cd}$ and $\mathrm{Ni}\left(\mathrm{r}=0.706^{* *}\right)$ and $\mathrm{Cd}$ and $\mathrm{Cr}\left(\mathrm{r}=0.667^{* *}\right)$ are positive and strong effect. This buttress the earlier suggestion and $\mathrm{Cd}$ and $\mathrm{Ni}$ are related to construction projects from the KLIA in the study area.

\section{Nickel (Ni)}

The highest Ni concentration was recorded at SW9 (32. $25 \mathrm{mg} \mathrm{kg}^{-1}$ ). This is a similar location of the highest concentration of $\mathrm{Cr}$ was recorded. Ni concentration at SW9 is found below the Dutch sediment guideline/Malaysian soil standard (Target and Intervention values). However, is approaching the concentrations of $35 \mathrm{mg} \mathrm{kg}^{-1}$ of the Target value. SW9 is the closest downstream locations to KLIA. Therefore, the relatively higher concentration of $\mathrm{Ni}$ at SW9 can be associated to the building materials used in the construction projects at KLIA. Nickel and nickel compounds have many industrial and commercial uses especially in metallurgy and as catalysts, pigments (paints) and alloys (Cempel and Nickel, 2005). The sources of nickel are the paints and varnishes, dye, building material, electrical equipment and telephone cable (Islam et al., 2015). Moreover, these same authors added that the concentration of Ni higher than any other location in polluted site may be due to construction materials, paint and varnishes. In addition, a considerable part of $\mathrm{Ni}$ could find its way into the environment as a result of the burning of diesel oil containing nickel (Barałkiewicz and Siepak, 1999). Therefore, in this study area Ni similar to $\mathrm{Cr}$ can be tied to construction activities around KLIA. Correlation analysis between $\mathrm{Cr}$ and $\mathrm{Ni}\left(\mathrm{r}=0.933^{* * *}\right)$ which were strong and positive suggest that the metals ( $\mathrm{Cr}$ and $\mathrm{Ni}$ ) could be associated to pollutions from construction projects from KLIA. In addition, since the cationic form $\mathrm{Ni}^{2+}$ can migrate together with its solutions over great distances (Barałkiewicz and Siepak, 1999). Then the KLIA could be implicated as the source of Ni and other heavy metals such as $\mathrm{Cr}$ identified in the study area due to construction activity.

\section{Zinc (Zn)}

There are no significant correlations between $\mathrm{Zn}$ and the other heavy metals. The exception is the relation of $\mathrm{Zn}$ and Fe. $\mathrm{Zn}$ exhibit almost similar pattern with $\mathrm{Fe}$ concentrations from midstream to downstream of the catchment area (refer to Table 3 ). Correlation coefficient analysis of $\mathrm{Zn}$ and $\mathrm{Fe}\left(\mathrm{r}=0.645^{*}\right)$ is strong and positive indicating that $\mathrm{Zn}$ and $\mathrm{Fe}$ are likely of the same source. The highest concentrations of $\mathrm{Zn}$ is at SW12 (114.28 mg $\mathrm{kg}^{-1}$ ) and this station (SW12) is closer to the Dengkil sand mine. Moreover, the value recorded in SW12 (114.28 $\mathrm{mg} \mathrm{kg}^{-1}$ ) is approaching the Canadian ISQG set at $123 \mathrm{mg} \mathrm{kg}^{-1}$. Some relatively higher concentrations were also observed at SW5 (55.32 $\left.\mathrm{mg} \mathrm{kg}^{-1}\right)$ and SW9 (49.83 $\mathrm{mg} \mathrm{kg}^{-1}$ ) which are also located close to the KLIA. However the downstream SW13 (55.48 $\mathrm{mg} \mathrm{kg}^{-1}$ ) were higher than SW5 and SW9. This results point to the fact that $\mathrm{Zn}$ concentrations were dependent on the sampling locations while the mining activity at Dengkil sand mine may be associated with the introduction of relatively higher $\mathrm{Zn}$ concentrations in the downstream areas. The primary anthropogenic sources of zinc in the 
environment (air, water, soil) are related to mining and metallurgic operations involving $\mathrm{Zn}$ and the use of commercial products containing Zn (Islam et al., 2015). In the same vein, Wuana and Okieimen (2011) pointed out that extensive $\mathrm{Zn}$ as well as $\mathrm{Pb}$ may be associated to mining and smelting and have resulted in contamination of soil that poses risk to human and ecological health. Although, Zn concentrations were dependent on locations due to the various activities in the stations, the Dengkil Sand Mine may be implicated as the major source of this metal (Zn) in SW12 and SW13. Relative to the compared standards, the mean concentrations of $\mathrm{Zn}$ in the sediments in all of the stations are below the compared guidelines. Therefore $\mathrm{Zn}$ is not heavy metal of concern in the Labu catchment.

\section{Lead $(\mathrm{Pb})$}

Lead concentration at upstream station SW1 (36.42 $\mathrm{mg} \mathrm{kg}^{-1}$ ) were almost similar in concentration to downstream SW13 (37.42 $\left.\mathrm{mg} \mathrm{kg}^{-1}\right)$. The concentrations in the other stations (SW2-SW12) were lower but not widely apart from the value recorded at these two stations (SW1 and SW13). The mean value is $26.23 \pm 5.33 \mathrm{mg} \mathrm{kg}^{-1}$. In comparison with the standards, $\mathrm{Pb}$ in SW1 and SW13 do not meet the limits set by the Canadian ISQG. Thus, the river bed sediment is polluted by heavy metal $\mathrm{Pb}$. Moreover, $\mathrm{Pb}$ concentration $\mathrm{SW} 1$ and SW13 have exceeded the average shale $(\mathrm{Bn})$ value (14.8). This indicates anthropogenic influences in the stations. The relatively higher concentrations of $\mathrm{Pb}$ in SW1 and SW13 suggest that the use of $\mathrm{Pb}$ related chemicals in these stations were more prevalent than the other stations. The relatively higher concentration in SW13 may be tied to the use of chemicals containing Pb in the oil palm plantation located in Dengkil area. The concentration in SW1 may be due to intense use of chemicals containing $\mathrm{Pb}$ due to agricultural practices in the location. The compounds used to supply essential elements $\mathrm{N}, \mathrm{P}, \mathrm{K}$ in fertilizer usually contain trace amounts of heavy metals such as $\mathrm{Cd}$ and $\mathrm{Pb}$ as impurities, which, after continued fertilizer, application may significantly increase their content in the soil (Jones and Jarvis, 1981). This same author added that pesticides for agriculture and horticulture purposes also contain $\mathrm{Cu}, \mathrm{Pb}$, or $\mathrm{Zn}$ e.g., fungicidal sprays. This may have been applied in agriculture cultivations and plantation and then washed down to surrounding riverbed. Therefore the activity promoting the elevated $\mathrm{Cu}, \mathrm{Zn}$ and $\mathrm{Pb}$ concentration in some of the stations may be associated to agriculture practices in the area. The correlation relation between $\mathrm{Pb}$ and $\mathrm{Cd}\left(\mathrm{r}=-0.677^{* *}\right)$ which were strong but negative confirms the different sources of the metals. This suggests further that $\mathrm{Pb}$ is due to agricultural practices while $\mathrm{Cd}$ as pointed out earlier is from construction activities in KLIA (although both metals are of anthropogenic origin). The level of $\mathrm{Pb}$ generally observed in all of the stations which were not widely varied (deviation is $5.33 \mathrm{mg} \mathrm{kg}^{-1}$ ) is not surprising because Labu Catchment is an area of intense agriculture, plantation and forest developments and signify the prevalent use of $\mathrm{Pb}$ chemicals. However, $\mathrm{Pb}$ is a dangerous chemical; it can cause serious injury to the brain, nervous system, red blood cells and kidneys (Baldwin and Marshall, 1999). Ingestion of $\mathrm{Pb}$ accumulates in the body organs (i.e., brain) may lead to poisoning (plumbism) or even death. The gastrointestinal tract, kidneys and central nervous system are also affected by the presence of $\mathrm{Pb}$ (Wuana and Okieimen, 2011).

\section{Arsenic (As)}

Arsenic (As) appear to be of a major concern in the study area than other heavy metal investigated. Arsenic (As) in all the thirteen stations was higher than the Canadian ISGQ standard set at $5.90 \mathrm{mg} \mathrm{kg}^{-1}$. Relatively higher concentrations are in the midstream areas at Batang Labu and Batang Nilai at SW5 (19.97 $\mathrm{mg} \mathrm{kg}^{-1}$ ) and SW6 $\left(17.59 \mathrm{mg} \mathrm{kg}^{-1}\right)$ respectively. These stations as pointed out earlier are locations with relatively higher concentrations of metal such as $\mathrm{Cu}, \mathrm{Zn}$ and $\mathrm{Cd}$. Relatively higher concentrations of As were recorded at upstream SW1 (11.57 $\left.\mathrm{mg} \mathrm{kg}^{-1}\right)$, immediate downstream SW9 (11.85 mg $\left.\mathrm{kg}^{-1}\right)$ and SW10 (11.23 mg kg-1). The furthest downstream area at SW12 and SW13 are also high in As concentrations (Table 3). Arsenic is present naturally in the aquatic and terrestrial environments owing to weathering and eroding of rock and soil (Gharibreza et al., 2013). Correlation analysis between $\mathrm{As}$ and $\mathrm{Cu}(\mathrm{r}=$ $0.806^{* * *}$ ) which was found to be positive and of strong effect suggest the anthropogenic source mainly agriculture and forest development in the area. Agriculture as a source of As pollutions is also similar source of $\mathrm{Cu}, \mathrm{Zn}$ and $\mathrm{Pb}$ pollution in the catchment. Therefore, As concentrations being higher than the average shale $(\mathrm{Bn})$ value $(1.7)$ in all the locations cannot be associated with the background geology/soils of the area but due to anthropogenic inputs in the same trend as the listed metals $(\mathrm{Cu}, \mathrm{Zn}$ and $\mathrm{Pb})$. Arsenic (As) containing pesticides from agriculture use such as lead arsenate can be leached downwards to river bed sediments or through the soil profile (Wuana and Okieimen, 2011). The metal (As) is dangerous and associated with skin damage, increased risk of cancer and problems with circulatory system (Scragg, 2006).

\section{Iron $(\mathrm{Fe})$}

The concentration of $\mathrm{Fe}$ was excessively higher that the other investigated heavy metal concentrations in the Labu River bed sediments at mean concentration value of $7636.39 \pm 2015.98 \mathrm{mg} \mathrm{kg}^{-1}$. This relatively higher value than other metals is due to the fact that Fe dominates in natural sources of its input (about 98\%) (Sinex and 
Wright, 1988). The deviation values $\left( \pm 2015.98 \mathrm{mg} \mathrm{kg}^{-1}\right)$ further indicates that the $\mathrm{Fe}$ concentrations in the sediment were not similar and widely varied. The highest concentration of $\mathrm{Fe}$ is observed to be at the midstream area SW5 (10707.7 mg kg${ }^{-1}$ ) and SW6 (10085.1 $\mathrm{mg} \mathrm{kg}^{-1}$ ). This was followed by high concentrations at downstream area in a progressively increasing pattern from SD10 to SD13 with a relatively higher value at the downstream in SD13 (9370.4 $\mathrm{mg} \mathrm{kg}^{-1}$ ). There is no standard guidelines value stipulated by the Dutch/Malaysian soil standard neither is there any by the Canadian sediment guidelines for comparison purposes. However, the strong correlation relationship found between $\mathrm{Fe}$ and $\mathrm{As}\left(\mathrm{r}=0.697^{* *}\right)$ is strong and positive. Moreover, As was associated to anthropogenic source. This suggest similar anthropogenic source of Fe pollutions. The association found between $\mathrm{Fe}$ and $\mathrm{Zn}\left(\mathrm{r}=0.645^{*}\right)$ and their increasing concentration pattern from midstream to downstream (Table 3) suggest the pattern of the redisposition of the riverbed sediments from midstream to downstream. However, the weak correlation found between $\mathrm{Fe}$ and $\mathrm{Ni}(\mathrm{r}=0.2799)$ discriminate between Agriculture practices as a source of pollution of $\mathrm{Fe}$ and construction activities related to KLIA as the source of pollution of $\mathrm{Ni}$ (although both metals Fe and $\mathrm{Ni}$ are due to the anthropogenic activities). Moreover the strong association found with $\mathrm{Fe}$ and $\mathrm{Cu}(\mathrm{r}=0.523)$ as indicated earlier establish that Fe were due to agricultural activities. Overall, the mean concentrations $(\mathrm{mg} / \mathrm{kg})$ and standard deviation values recorded for the heavy metals are therefore in the order: Fe $(7636.39 \pm 2015.98)>\mathrm{Zn}$ $(39.43 \pm 26.38)>\mathrm{Pb}(26.23 \pm 5.33)>\mathrm{Cr}(19.74 \pm 10.36)>\mathrm{As}$ $(11.67 \pm 3.59)>\mathrm{Ni}(9.48 \pm 7.56)>\mathrm{Cu}(7.33 \pm 2.35)>\mathrm{Cd}$ $(0.097 \pm 0.03)$. Among these metals, three: $\mathrm{Cr}$, As and $\mathrm{Pb}$ parameters as indicated by the ISQG are heavy metal of concern in river bed sediments in individual stations in the Labu river catchment. Whereas $\mathrm{Ni}$ and $\mathrm{Zn}$ also need to be carefully checked as it is approaching the Malaysian/Dutch Target value and ISQG in some stations.

\section{Pollution Status by Geoaccumulation Index (Igeo)}

The Igeo values of studied heavy metals at sampling stations are shown in Table 5. The results of the Igeo showed that $\mathrm{Cr}, \mathrm{Cu}, \mathrm{Pb}$ and $\mathrm{Ni}$ in all of the stations do not exceed their background values $\left(B_{n}\right)$ with the exception of As. The Igeo mean values calculated were: $\mathrm{Cr}(-3.38 \pm 0.17), \mathrm{Cu}(-3.22 \pm 0.12)$, Ni (-3.37 \pm 0.24$), \mathrm{Zn}(-$ $2.14 \pm 0.23), \mathrm{Cd}(-3.38 \pm 0.17)$ and $\mathrm{Pb}(-3.22 \pm 0.12)$. The Igeo values, when compared with the class intensity in Table 2 were found to fall in geoaccumulation class intensities of zero (0) signifying that these metals with reference to the Igeo index were practically uncontaminated and this trends is seen in all of the investigated stations. However, the heavy metals As in the sediments were found to be contaminated in all the stations from SW1-SW13. The mean Igeo values for As is $2.14 \pm 0.13$ and the deviating value in the sediments showed that the pollution level were almost similar in all of the stations. Geoaccumulation index (Igeo) for As was between the ranges of 1.37-2.97. The class intensity is 2 and hence is "moderately contaminated". The highest Igeo values for As was found in SW5 and SW6 at Batang Labu and Batang Nilai. The value recorded in SW9-SW13 were also high compared with the upstream stations suggesting that this metal (As) were elevated due to anthropogenic activity and may be linked to agriculture and disturbances of the soils in the area and therefore is in agreement with the earlier results.

Table 5. Geoaccumulation index (Igeo) value of eight (8) investigated heavy metals for the river bed sediments from thirteen (13) stations in Labu Catchment

\begin{tabular}{|c|c|c|c|c|c|c|c|}
\hline Stations & Igeo $\mathrm{Cr}$ & Igeo $\mathrm{Cu}$ & Igeo $\mathrm{Ni}$ & Igeo $\mathrm{Zn}$ & Igeo As & Igeo $\mathrm{Cd}$ & Igeo $\mathrm{Pb}$ \\
\hline$\overline{\text { SW1 }}$ & -3.63 & -3.08 & -3.75 & -2.85 & 2.18 & -1.57 & 0.71 \\
\hline SW2 & -3.73 & -3.46 & -3.87 & -2.76 & 1.91 & -0.85 & 0.16 \\
\hline SW3 & -3.76 & -3.59 & -4.13 & -2.70 & 1.66 & -0.60 & 0.33 \\
\hline SW4 & -4.01 & -3.82 & -4.27 & -2.96 & 1.37 & -1.16 & 0.19 \\
\hline SW5 & -3.12 & -2.72 & -3.35 & -1.37 & 2.97 & -0.20 & 0.25 \\
\hline SW6 & -3.24 & -2.43 & -2.71 & -1.71 & 2.79 & -0.39 & 0.01 \\
\hline SW7 & -3.81 & -3.06 & -2.79 & -2.62 & 2.32 & -0.56 & 0.24 \\
\hline SW8 & -3.62 & -3.61 & -3.64 & -2.70 & 2.10 & -0.48 & -0.25 \\
\hline SW9 & -1.87 & -2.88 & -1.38 & -1.52 & 2.22 & -0.04 & 0.07 \\
\hline SW10 & -2.83 & -3.01 & -2.62 & -2.14 & 2.14 & -0.30 & 0.03 \\
\hline SW11 & -3.40 & -3.26 & -3.89 & -1.99 & 1.89 & -0.79 & 0.28 \\
\hline SW12 & -3.57 & -3.70 & -3.98 & -0.32 & 2.08 & -0.68 & 0.03 \\
\hline SW13 & -3.32 & -3.85 & -4.00 & -1.36 & 2.15 & -1.32 & 0.75 \\
\hline${ }^{\mathrm{a}} \mathrm{Bn}$ & 126 & 45 & 56 & 95 & 1.7 & 0.1 & 14.8 \\
\hline Mean & -3.38 & -3.22 & -3.37 & -2.14 & 2.14 & -3.38 & -3.22 \\
\hline SD & \pm 0.17 & \pm 0.12 & \pm 0.24 & \pm 0.23 & \pm 0.13 & \pm 0.17 & \pm 0.12 \\
\hline Minimum & -4.01 & -3.82 & -4.27 & -2.96 & 1.37 & -4.01 & -3.82 \\
\hline Maximum & -1.87 & -2.43 & -1.38 & -0.32 & 2.97 & -1.87 & -2.43 \\
\hline
\end{tabular}

Note: \pm denotes Standard Deviation (SD); negative values indicate uncontaminated sediments ${ }^{\text {a Bn-indicates geochemical background }}$ value of global average shale- Source: Wedepohl (1995) 


\section{Conclusion}

Eight heavy metals investigated in the Labu catchment has helped to understand the pollution levels and the associated sources in the catchment. Heavy metals $\mathrm{As}, \mathrm{Cr}$ and $\mathrm{Pb}$ were implicated by the Canadian interim sediment guidelines (ISQG) as the heavy metal of concern in the river bed in the different stations. Whereas, the Dutch Target value and CCME (ISQG) standard guidelines point to $\mathrm{Ni}$ and $\mathrm{Zn}$ as metals that needs to be carefully checked as they were approaching the set limit values. The geoaccumulation index gave the conclusive evidence that the geochemical background of the metals were not exceeded and were uncontaminated with the exception of As. the geochemical background of As in the sediments from upstream to downstream have been exceeded and were classified as "moderately contaminated". The variability in the distribution of heavy metals (Fe, As, $\mathrm{Cu}, \mathrm{Zn}, \mathrm{Cr}, \mathrm{Ni}, \mathrm{Cd}$ and $\mathrm{Pb}$ ) reflects responses due to activities in the sampling stations. Based on mean values of the heavy metal concentrations with the compared standards and the geoaccumulation index (Igeo), it is concluded that As is the major heavy metal of concern and were polluting the river bed sediments at the Labu catchment. There is need for the authorities to pay more attentions to sediment pollution problem due to As and address riverbed sediment pollution problem in the different locations as indicated by ISQG due to anthropogenic influences from Dengkil Sand Mine and heavy metal inputs from construction projects from neighboring KLIA and agriculture practices in the area. Therefore, the situation in the catchments needs to be given priority attention.

\section{Acknowledgement}

The authors wish to acknowledge the support of the Faculty of Science and Technology UKM for providing the facilities to carry out this research. This research is partly supported by research grant AP2013-004 and ZF-2013-012.

\section{Author's Contributions}

Ahmad Shoaib Jahesh: Participated in all experiments, data analysis and the writing of the manuscript.

Sahibin Abd Rahim: Organized the study, responsible for idealistic, editing of manuscript.

Wan Mohd Razli Idris: Participated in the dataanalysis and editing of manuscript.

\section{Ethics}

This article contains unpublished and original work of the authors. All authors are in one consent as regards to the manuscript and have read and approved the manuscript and no ethical issues involved.

\section{References}

Aboud, S.J. and N. Nandini, 2009. Heavy metal analysis and sediment quality values in urban lakes. Am. J. Environ. Sci., 5: 678-687. DOI: 10.3844/ajessp.2009.678.687

Adnan, S.S.B.M., Y.S. Yusoff and C.Y. Piaw, 2013. Soil chemistry and pollution study of a closed landfill site at Ampar Tenang, Selangor, Malaysia. Waste Manage. Res., 31: 599-612.

DOI: $10.1177 / 0734242 X 13482031$

APN and EOC., 2013. Land use and land cover change for Southeast Asia. A Synthesis Report. Final report submitted to Asia Pacific Network (APN) for global change research and Earth Observation Centre (EOC) UKM.

Baldwin, D.R. and W.J. Marshall, 1999. Heavy metal poisoning and its laboratory investigation. Ann. Clin. Biochem., 36: 267-300. DOI: $10.1177 / 000456329903600301$

Barałkiewicz, D. and J. Siepak, 1999. Chromium, nickel and cobalt in environmental samples and existing legal norms. Polish J. Environ. Stud., 8: 201-208.

Boszke, L., T. Sobczyński, G. Głosińska, A. Kowalski and J. Siepak, 2004. Distribution of mercury and other heavy metals in bottom sediments of the middle Odra River Germany/Poland. Polish J. Environ. Stud., 13: 495-502.

CCME, 2002. Canadian sediment quality guidelines for the protection of aquatic life: Summary tables. Canadian Council of Ministers of the Environment, Winnipeg, Canada.

Cempel, M. and G. Nikel, 2005. Nickel: A review of its sources and environmental toxicology. Polish J. Environ. Stud., 15: 375-382.

Farkas, A., E. Claudio and V. Luigi, 2007. Assessment of the environmental significance of heavy metal pollution in sediments of the River Po. Chemosphere, 68: 761-768.

DOI: $10.1016 /$ j.chemosphere.2006.12.099

Forstner, U., W. Ahlf and W. Calmano, 1993. Sediment quality objectives and criteria development in Germany. Water Sci. Technol., 28: 307-316.

Gharibreza, M., M.A. Ashraf. I. Yusoff and J.K. Raj, 2013. An evaluation of Bera Lake (Malaysia) sediment contamination using sediment quality guidelines. J. Chem. DOI: 10.1155/2013/387035

Gupta, S., J. Vinod, N. Matic. V. Kapralova and J.S. Solanki, 2014. Assessment of geo-accumulation index of heavy metal and source of contamination by multivariate factor analysis. Int. J. Hazardous Mater., 2: 18-22.

Hoo, L.S., A. Samat and R.M. Othman, 2005. Effects of wet deposition on levels of selected heavy metals in Labu River: A snapshort study of a sub-urban Lotic Ecosystem. Sains Malaysia, 34: 129-133. 
Islam, M.D., S.S. Majumder, A. Al Mamun, M.B. Khan and M.A. Rahman et al., 2015. Trace metals concentrations at the atmosphere particulate matters in the southeast Asian Mega City (Dhaka, Bangladesh). Open J. Air Pollut., 4: 86-98. DOI: 10.4236/ojap.2015.42009

Ismail, S.N.S., C.F. Shak, M.A.A. Samah, E.M. Hatta and A.S.A. Wahab, 2015. Soil contamination from non-sanitary waste landfill in langat water catchment area, Malaysia. J. Sci. Res. Reports, 7: 480-493. DOI: $10.9734 / \mathrm{jsrr} / 2015 / 15102$

Jones, L.H.P. and S.C. Jarvis, 1981. The Fate of Heavy Metals. In: The Chemistry of Soil Processes, Green, D.J. and M.H.B. Hayes, (Eds.), John Wiley and Sons, New York, ISBN-10: 0471276936.

Kimbrough, D.E., 1989. Acid digestion, sludge, soils and solid wastes. A proposal alternative to the EPA SW 846 method 3050. Environ. Sci. Technol., 23: 896-900. DOI: 10.1021/es00065a021

Kirpichtchikova, T.A., A. Manceau, L. Spadini, F. Panfili and M.A. Marcus et al., 2006. Speciation and solubility of heavy metals in contaminated soil using X-ray micro fluorescence, EXAFS spectroscopy, chemical extraction and thermodynamic Modeling. Geochimica Cosmochimica Acta, 70: 2163-2190. DOI: 10.1016/j.gca.2006.02.006

Lin, Y.P., T.P. Teng and T.K. Chang, 2002. Multivariate analysis of soil heavy metal pollution and landscape in Changhua Country in Taiwan. Landscape Urban Plan., 62: 19-35. DOI: $10.1016 / \mathrm{S} 0169-2046(02) 00094-4$

MacFarlane, G.R., C.E. Koller and S.P. Blomberg, 2007. Accumulation and partitioning of heavy metals in mangroves: A synthesis of field-based studies. Chemosphere, 69: 1454-1464. DOI: 10.1016/j.chemosphere.2007.04.059

Mohammed, S., 2005. The Malay pottery in Malaysia. Proceedings of the Asia Ceramics Network Conference, Jan. 12-18, Seoul, South Korea pp: 77-79.

Muller, G., 1981. Heavy metal contamination of the sediments of the Ganga, Neckar, Elbe and Warta rivers and its major tributaries-A survey. Chemiker Zeitung, 105: 157-164.

Praveena, S.M., A. Ahmed, M. Radojevic, M.H. Abdullah and A.Z. Aris, 2008. Heavy Metals in mangrove surface sediment of mengkabong lagoon, Sabah: Multivariate and geo-accumulation index approaches. Int. J. Environ. Res., 2: 139-148.

Sakawi, S., M. Atta and M.F.M. Jali, 2013. Possibility of heavy metal contaminated solid waste from municipal waste disposal site in Pangkor Island Perak State Malaysia. Res. J. Applied Sci., 8: 14-21.

DOI: $10.3923 /$ rjasci.2013.14.21
Sany, B.T., A.H. Sulaiman, G.H. Monazami and S, 2011. Assessment of sediment quality according to heavy metal status in the West Port of Malaysia. Int. J. Environ. Chem. Ecol. Geol. Geophys. Eng., 5: 111-115.

Scragg, A., 2006. Environmental Biotechnology. 2nd Ed, Oxford University Press, Oxford, UK, ISBN-10: 0199268673.

Shaharuddin, A. and H. Noorazuan, 2006. Analyzing rain patterns and trends in Negeri Sembilan using the GIS Polygon Thiessen and Isohyet Contours methods. Geografia Online, Malaysian J. Society Space, 2: 105-113.

Sheriza, M.R., N.A. Ainuddin, A.H. Hazandy and M.S.H. Zulhaidi, 2011. Annual rainfall estimation based on two different methods. J. Environ. Hydrol., 19: $1-9$

Sinex, S.A. and D.A. Wright, 1988. Distribution of trace metals in the sediments and biota of Chesapeake bay. Mar. Pollut. Bull., 19: 425-431. DOI: 10.1016/0025-326X(88)90397-9

Smith, L.A., J.L. Means, A. Chen, B. Alleman and C.C. Chapman et al., 1995. Remedial Options for Metals-Contaminated Sites. 1st Edn., CRC-Press, ISBN-10: 1566701805, pp: 240.

Salomons, W. and U. Forstner, 1984. Metals in the Hydrocycle. Springer Science and Business Media, Berlin, ISBN-10: 3642693253, pp: 352.

SPSS, 2013. PASW statistics for window. Statistical Package for Social Science Inc., Chicago.

Swartjes, F.A., 1999. Risk-based assessment of soil and groundwater quality in the Netherlands: Standards and remediation urgency. Risk Analysis, 19: 1235-1249. DOI: 10.1111/j.1539-6924.1999.tb01142.x

Tanghinia, H.A., H.T. Basavarajappa and A.M. Qaid Saeed, 2010. Heavy metal pollution in Kabini River sediments. Int. J. Environ. Res., 4: 629-636.

Wedepohl, K.H., 1995. The composition of the continental crust. Geochimica et Cosmochimica Acta, 59: 1217-1232. DOI: 10.1016/0016-7037(95)00038-2

Wei, B. and L. Yang, 2010. A review of heavy metal contaminations in urban soils, urban road dusts and agricultural soils from China. Microchemical J., 94: 99-107. DOI: 10.1016/j.microc.2009.09.014

Wojtkowska, M., 2011. Content of selected heavy metals in water and riverbed sediments of the Utrata River. Environ. Protect. Eng., 37: 55-62.

Wuana, R.A. and F.E. Okieimen, 2011. Heavy metals in contaminated soils: A review of sources, chemistry, risks and best available strategies for remediation. ISRN Ecol., 2011: 1-20. DOI: 10.5402/2011/402647 